\title{
PENERAPAN MODEL PEMBELAJARAN KOOPERATIF TIPE GROUP INVESTIGATION BERBANTUAN MEDIA VISUAL UNTUK MENINGKATKAN HASIL BELAJAR IPA SISWA KELAS V SD BANJAR JAWA 3
}

\author{
Rindhy Anggreany Sagita Nggebu', Nyoman Kusmariyatni ${ }^{2}$ \\ 1,2Jurusan PPG PGSD SM3T \\ Universitas Pendidikan Ganesha \\ Singaraja, Indonesia \\ rnggebu@gmail.com, nyoman.kusmariyatni@gmail.com
}

\begin{abstract}
The purpose of this study was to improve the learning outcomes of natural science through the application of cooperative learning model type investigation group assisted visual media in grade 5 elementary scholl (SD) Negeri 3 Banjar Java. This research is a classroom action research conducted in two action cycles. The subject of this study was the $5^{\text {th }}$ grade students of SDN 3 Banjar Java in the school year 2018/2019 as many as 32 students. Data collection of this result of learning science in this study was carried out by using essay-shaped test methods. Then the data is analyzed by using qualitative desktop descriptive and quantitative descriptive techniques.

The research data shows that in the firstcycle the data of learning outcomes of IPA reached 74,06 $\%$ in the medium category and in the second cycle it reached $85,31 \%$ in the high category. Thus, increasing science learning outcomes reached $11,25 \%$. The result of this study indicate that cooperative learning model type investigation group assisted visual media can improve science learning outcomes for grade $5 b$ students in semester 1 of 2018/2019 school year at SDN 3 banjar Java.
\end{abstract}

Keywords: Cooperative Learning Model Type Investigation Group; Visual Media;Science Learning Outcomes

\begin{abstract}
Abstrak
Tujuan penelitian ini adalah untuk meningkatkan hasil belajar IPA melalui penerapan model pembelajaran kooperatif tipe Group Investigation berbantuan media visual di kelas VB SDN 3 Banjar Jawa. Penelitian ini adalah penelitian tindakan kelas (PTK) yang dilaksanakan dalam 2 siklus tindakan. Subjek penelitian ini adalah siswa kelas VB SDN 3 Banjar Jawa Tahun ajaran 2018/2019, sebanyak 32 orang siswa. Pengumpulan data hasil belajar IPA dalam penelitian ini dilakukan dengan menggunakan metode tes berbentuk esai. Selanjutnya data tersebut dianalisis dengan teknik deskriptif-kualitatif dan deskriptif-kuantitatif.

Data hasil penelitian menunjukan pada siklus I data hasil belajar IPA mencapai $74,06 \%$ berada pada kategori sedang dan pada siklus II mencapai $85,31 \%$ berada pada katagori tinggi. Dengan demikian, peningkatan hasil belajar IPA mencapai $11,25 \%$. Hasil penelitian ini menunjukkan bahwa penerapan model pembelajarn kooperatif tipe Group Investigation berbantuan media visual dapat meningkatkan hasil belajar IPA siswa kelas VB semester I tahun pelajaran 2018/ 2019 di SD Negeri 3 Banjar Jawa.
\end{abstract}

Kata-kata kunci: model pembelajaran kooperatif tipe Group Investigation ;media visual;hasil belajar IPA 


\section{PENDAHULUAN}

Pendidikan adalah suatu upaya untuk membentuk watak dan mencerdaskan kehidupan bangsa. Pendidikan menjadi ujung tombak dalam kemajuan bangsa yang harus terus ditingkatkan agar nantinya menciptakan sumber daya manusia yang memiliki daya saing tinggi. Untuk mencapai kemajuan pendidikan tentunya kurikulum pada pendidikan harus terus dikembangkan agar sesuai dengan tuntutan zaman. Kurikulum 2013 menganut pandangan dasar bahwa suatu pengetahuan tidak dapat dipindahkan begitu saja dari guru ke siswa. Siswa didorong untuk menemukan sendiri dan mentransformasikan informasi kompleks, mengecek informasi baru dengan yang sudah ada dalam ingatannya, dan melakukan pengembangan menjadi informasi atau kemampuan yang sesuai dengan lingkungan siswa. Dengan kata lain pembelajaran harus bergeser dari menerima informasi menjadi aktif mencari informasi.

Pembelajaran dalam kurikulum 2013 menggunakan sistem tema (tematik integratif). Dimana dalam beberapa pertemuan siswa mempelajari beberapa muatan materi yang tergabung dalam satu tema. Tema merajut makna berbagai konsep dasar sehingga siswa tidak belajar secara parsial. Dalam pembelajaran menggunakan kurikulum 2013 beberapa muatan pelajaran diintegrasikan ke dalam tema-tema seperti Bahasa Indonesia, IPA, IPS, SBdP sedangkan pelajaran Matematika dan PJOK dipisahkan dari tema. Matematika merupakan salah satu muatan pembelajaran yang terpisah dari tema. Oleh karena itu, matematika merupakan muatan yang penting karena matematika merupakan ilmu universal yang melandasi perkembangan teknologi modern, mempunyai peran dalam berbagai disiplin, memajukan daya pikir manusia. Dengan demikian, IPA memberikan manfaat bagi siswa agar nantinya siswa memiliki kemampuan berfikir logis, analitis, sistematis, kritis dan kreatif serta kemampuan bekerjasama. Menurut Aisyah (2007:1-3) kompetensi tersebut sangat penting bagi siswa agar siswa dapat memiliki kemampuan memperoleh informasi, mengelola dan memanfaatkan informasi untuk bertahan hidup pada keadaan yang tak pasti, selalu berubah dan kompetitif.

Berdasarkan observasi yang telah dilakukan pada tanggal 6 Februari 2018 di kelas VB SD Negeri 3 Banjar Jawa, ditemukan rata - rata hasil belajar IPA sebagian besar siswa masih berada pada kategori sedang dengan nilai dibawah 80. Dari seluruh siswa yang berjumlah 32 orang, siswa yang berada pada kategori tinggi berjumlah 12 orang $(37,5 \%)$ dan siswa yang kategori sedang berjumlah 20 orang $(62,5 \%)$. Selain itu, kurangnya penggunaan media dalam kegiatan pembelajaran untuk mempermudah pemahaman siswa terkait materi yang disampaikan. Dengan demikian dari permasalahan yang telah dipaparkan, hasil belajar pada pengetahuan IPA siswa SD Negeri 3 Banjar Jawa kelas V B perlu ditingkatkan sehingga membantu siswa untuk mencapai hasil belajar yang optimal dengan menerapkan model pembelajaran kooperatif tipe Group Investigation berbantuan media visual.

Menurut Huda (2013:292) menyatakan bahwa Group Investigation (Gl) adalah salah satu metode kompleks dalam pembelajaran kelompok yang mampu membuat siswa untuk menggunakan kemampuan berfikir tingkat tinggi. Menurut Shoimin (2014:83 ) Group Investigation merupakan model pembelajaran yang lebih menekankan pada pilihan dan kontrol siswa dari pada menerapkan teknik-teknik pengajaran di ruang kelas. Selain menggunakan model pembelajaran kooperatif tipe Group Investigation untuk meningkatkan hasil belajar pengetahuan alam siswa, perlunya upaya untuk mengoptimalkan model pembelajaran dengan menggunakan media visual sebagai media bantuan agar lebih menarik dan mudah dipahami siswa. Menurut Zainal Aqib (2014:50) menyatakan bahwa media pembelajaran dapat menyalurkan pesan dan merangsang terjadi proses belajar pada siswa.

Sejalan dengan pendapat Kusumayanti (2013) menyatakan, bahwa media visual sebagai suatu media yang benar-benar tampak, nyata dan benar-benar ada yang bisa siswa perhatikan dengan menggunakan alat indra dan siswa tidak mengkhayal dengan apa yang dipelajarinya. Melalui media visual siswa dapat lebih memahami apa yang sedang dipelajari karena dengan media yang nyata yang menarik serta cocok dengan kehidupan siswa yang sebenarnya, siswa lebih mudah untuk menangkap pelajaran.

Upaya untuk meningkatkan hasil belajar ipa siswa secara teoretis dapat dilaksanakan melalui model pembelajaran kooperatif tipe Group Investigation berbantuan media visual, dengan demikian bahwa "Penerapan Model Pembelajaran Group Investigation berbantuan media visual diharapkan dapat Meningkatkan Hasil Belajar IPA pada siswa Kelas VB SD Negeri 3 Banjar Jawa Tahun Ajaran 2018/2019". 


\section{Metode}

Penelitian ini adalah penelitian tindakan kelas (PTK). Penelitian ini dilaksanakan bersiklus dengan mengacu pada model Kemmis dan Taggart yang terdiri dari 4 (empat) tahapan dasar yang saling terkait dan berkesinambungan:

(1)perencanaan (planning), (2) pelaksanaan (acting), (3) pengamatan (observing), dan (4) refleksi (reflecting) (Kasbollah, 1998).

Penelitian ini dilaksanakan di Kelas V SD Negeri 3 Banjar Jawa pada semester I tahun pelajaran 2018/2019. Penelitian dilakukan bulan Juli sampai bulan Oktober 2018. Subyek penelitian adalah siswa kelas V SD Negeri 3 Banjar Jawa yang berjumlah 32 orang terdiri dari laki-laki 15 orang dan perempuan 17 orang. Jenis data dalam penelitian ini adalah data kualitatif, yang meliputi hasil observasi aktivitas siswa dan guru. Data kuantitatif, meliputi data yang diperoleh dari tes hasil belajar siswa.

Data kualitatif diperoleh dengan cara mengamati situasi belajar mengajar pada saat dilaksanakan tindakan yang diambil dengan menggunakan lembar aktivitas siswa dan lembar aktivitas guru dan data kuantitatif diperoleh dari hasil belajar siswa melalui tes/evaluasi yang diberikan setiap tindakan

dengan tujuan untuk mengetahui peningkatan hasil belajar siswa terhadap materi yang telah diajarkan pada tiap siklus.

Data yang dikumpulkan dalam penelitian ini adalah data mengenai hasil belajar IPA siswa. Metode pengumpulan data yang digunakan dalam penelitian ini adalah metode tes dan metode observasi.

\section{Metode Tes}

Metode tes merupakan salah satu metode untuk mengumpulkan data yang ingin diperoleh pada objek tertentu. Menurut Agung, (2012:66) metode tes dalam penelitian adalah cara memperoleh datayang berbentuk suatu tugas yang dilakukan dan dikerjakan oleh seorang atau sekelompok orang yang dites (testee) dan dari tes tersebut dapat menghasilkan suatu data berupa skor. Tes merupakan instrumen alat ukur untuk pengumpulan data dimana dalam memberikan respon atas pertanyaan dalam instrumen, peserta didorong untuk menunjukkan penampilan maksimalnya. Menurut Widoyoko (2014:51) "tes merupakan salah satu alat untuk melakukan pengukuran, yaitu alat untuk mengumpulkan informasi karakteristik suatu objek yang diantara objek tes adalah kemampuan siswa". Tes yang digunakan dalam penelitian ini adalah tes tertulis dalam bentuk esai.

\section{Metode Observasi}

Observasi merupakan suatu cara untuk memperoleh data yang terdiri dari kegiatan pengamatan dan pencatatan pada suatu objek. Menurut Irham dan Wiyani (2013:239), "observasi atau pengamatan merupakan cara menghimpun data atau bahan-bahan keterangan yang dilakukan dengan mengadakan pengamatan dan pencatatan secara sistematis terhadap fenomena-fenomena yang sedang dijadikan sasaran pengamatan". Selanjutnya menurut Agung (2012: 61) "metode observasi adalah suatu cara untuk memperoleh data dengan jalan mengadakan pencatatan dan pengamatan secara sistematis tentang suatu objek tertentu". Jadi dapat disimpulkan bahwa metode observasi ini adalah suatu cara dalam memperoleh informasi dengan melakukan suatu pengamatan terhadap suatu objek.

Tujuan dari penggunaan metode observasi ini adalah untuk mengetahui secara langsung proses pembelajaran yang dilakukan dalam penerapan model pembelajaran kooperatif tipe Group Investigation berbantuan media visual. Pelaksanaan observasi tersebut dibantu oleh guru wali kelas sehingga diperoleh data yang bersifat objektif.

Jadi metode observasi ini hanya digunakan untuk mengetahui keoptimalan proses pembelajaran dengan menerapkan model pembelajaran kooperatif tipe Group Investigation berbantuan media visual.

Hasil observasi tidak dianalisis sebagai data hasil penelitian.

\section{Instrumen Penelitian}


Menurut Sugiyono (2013: 148 ) "Instrumen penelitian adalah suatu alat yang digunakan untuk mengukur fenomena alam ataupun fenomena sosial yang diamati". Instrumen yang digunakan dalam penelitian ini berupa butir-butir tes atau pertanyaan berbentuk tes esai. Instrumen berupa butir-butir tes atau pertanyaan berbentuk tes esai ini berjumlah 5 butir digunakan untuk mengukur hasil belajar pengetahuan matematika yang diterapkan setiap akhir siklus. Tes hasil belajar IPA memuat materi pembelajaran yang dibahas pada pertemuan I dan II pada siklus I dan II masing-masing soal diberi bobot 20 sehingga diperoleh skor maksimal ideal $(\mathrm{SMI})=100$.

Tes esai yang digunakan sesuai dengan syarat-syarat tes yang baik yaitu memenuhi validitas isi (content validity). Menurut Puwanto (2013:120) "validitas isi adalah pengujian validitas yang dilakukan atas isinya untuk memastikan bahwa tes hasil belajar sesuai dengan keadaan yang dalam penelitian ini untuk menganalisis data hasil belajar IPA.

Setelah data dalam penelitian ini terkumpul, maka selanjutnya dilakukan analisis data. Analisis data ini dimaksudkan untuk mengetahui peningkatan hasil belajar matematika siswa kelas VB SD Negeri 3 Banjar Jawa Tahun Ajaran 2018/2019.

Setelah didapatkan skor hasil belajar kompetensi pengetahuan dengan pedoman skor, maka ditentukan nilai masing masing siswa dengan rumus : Menentukan rata - rata kompetensi IPA dengan cara mencari mean yaitu ingin diukur yaitu hasil belajar matematika". Uji validitas isi dilakukan dengan cara

menyesuaikan butir tes dengan indikator, kompetensi dasar dan kompetensi inti yang dituangkan dalam kisi-kisi.

Pengujian validitas isi ini dilakukan dengan meminta pertimbangan dari dosen pembimbing. Terkait dengan hal tersebut, maka untuk kisi-kisi soal hasil belajar IPA yang digunakan dalam penelitian ini disusun dan dikonsultasikan dengan dosen pembimbing dan guru kelas VB di SD Negeri 3 Banjar Jawa.

Sementara kegiatan observasi proses pembelajaran dalam model pembelajaran kooperatif tipe Group Investigation menggunakan instrumen berupa lembar observasi. Untuk lembar observasi kegiatan pembelajaran disajikan secara terlampir. Penelitian ini menggunakan teknik analisis data yaitu analisis deskriptif kualitatif dan analisis deskriptif kuantitatif. Analisis deskriptif kualitatif adalah suatu cara analisis/pengelolaan data dengan jalan menyusun secara sistematis dalam bentuk kalimat atau kata-kata, mengenai suatu objek yang diteliti sehingga memperoleh kesimpulan umum. "Analisis deskriptif kuantitatif adalah suatu cara pengelolaan data yang dilakukan dengan jalan menyusun secara sistematis dalam bentuk angka-angka dan persentase, mengenal suatu objek yang diteliti sehingga memperoleh kesimpulan yang umum" (Agung, 2012:67). Analisis deskriptif kualitatif dan analisis deskriptif kuantitatif digunakan

\section{HASIL DAN PEMBAHASAN}

Hasil tes yang dilakukan melalui observasi awal diperoleh ketuntasan klasikal 52,5\%, daya serap klasikal 65,9\% dan hasil belajar klasikal rata-rata 65,9.

Kegiatan yang dilakukan pada tahap ini adalah mengumpulkan data skor awal hasil belajar IPA siswa kelas VB SD Negeri 3 Banjar Jawa dengan melihat hasil ulangan siswa pada daftar nilai yang diperlihatkan guru kelas. Hal tersebut dimaksudkan untuk mengetahui rata - rata persentase hasil belajar matematika sebelum dilakukan tindakan dan sebagai skor awal. Data tersebut digunakan untuk lebih menguatkan hasil observasi dan wawancara yang telah dilakukan sebelumnya yaitu bahwa di kelas tersebut persentase rata - rata hasil belajar matematika siswa kelas VB masih berada pada kategori sedang.

Berdasarkan hasil analisis data siklus I, maka tingkat hasil belajar IPA secara klasikal dalam muatan pembelajaran dapat ditentukan dengan rumus sebagai berikut.

Berdasarkan analisis di atas maka skor rata-rata hasil belajar IPA secara klasikal mencapai 74,06 dengan skor perolehan 2.370. Kemudian hasil rata-rata tersebut dihitung ke dalam M\% sebagai berikut. belajar IPA untuk siklus I berada pada kategori sedang.

Hasil Penelitian Tindakan Kelas Siklus I Pelaksanaan tindakan pada siklus I

dilaksanakan mulai tanggal 10 Juli - 31 Agustus 2018 dengan 2 kali pertemuan. Kegiatan pembelajaran dilaksanakan pada pertemuan I dan pertemuan II, serta pada pertemuan III dilakukan tes akhir siklus I hasil belajar IPA dengan menggunakan soal uraian berbentuk esai. Secara umum pelaksanaan tindakan dilaksanakan dalam delapan fase kegiatan pembelajaran sesuai dengan fase yang ada pada model pembelajaran kooperatif 
tipe Group Investigation berbantuan media visual. Kedelapan fase tersebut yaitu: fase ke-1: guru membagi kelas menjadi beberapa kelompok yang heterogen. Fase ke-2: guru menjelaskan maksud pembelajaran dan tugas kelompok yang harus di kerjakan. Fase ke-3: guru mengundang ketua - ketua kelompok untuk memanggil materi tugas secara kooperatif dalam kelompoknya. Fase ke-4: masing - masing kelompok membahas materi tugas secara kooperatif dalam kelompoknya. Fase ke-5: Setelah selesai, masing - masing kelompok yang diwakili ketua kelompok atau salah satu anggotanya menyampaikan hasil pembahasan. Fase ke 6

: Kelompok lain dapat memberikan tanggapan terhadap hasil pembahasan. Fase ke 7 : Guru memberikan penjelasan singkat (klarifikasi) bila terjadi kesalahan konsep dan memberikan kesimpulan. Fase ke 8 : Evaluasi

\section{Data Hasil Belajar IPA Siklus I}

Data hasil belajar IPA dalam pembelajaran dengan penerapan model pembelajaran kooperatif tipe Group Investigation berbantuan media visual, diperoleh dari tes hasil belajar IPA

$$
\begin{aligned}
& \mathrm{M} \% \square \frac{\mathrm{M}}{\mathrm{SMI}} \square 100 \% \\
& \mathrm{M} \% \square \stackrel{\square, 06}{-\square 100 \%} \\
& \mathrm{M} \%=74,06 \%
\end{aligned}
$$

Presentase hasil belajar matematika siswa kelas VB adalah $74,06 \%$, dan apabila dikonversikan ke dalam PAP skala lima untuk kriteria hasil belajar matematika secara klasikal maka persentase rata- rata hasil

\section{Siklus I}

Hasil yang diperoleh pada tindakan siklus I meliputi, aktivitas guru rata-rata 4,3 dengan persentase keterlaksanaan $80 \%$ (dilaksanakan dengan baik), aktivitas siswa terlaksana rata-rata 2.5 (mulai berkembang), hasil belajar kognitif rata-rata 68,7 daya serap klasikal 68,7 dan ketuntasan klasikal 65\%, afektif rata-rata 3,2 (mulai berkembang), dan psikomotor rata-rata 3,2 (mulai berkembang).

\section{Siklus II}

Hasil yang diperoleh pada tindakan siklus I yaitu: aktivitas guru rata-rata 4,9 dengan persentase keterlaksanaan $90 \%$ (dilaksanakan dengan baik), aktivitas siswa terlaksana ratarata 3,6 (membudaya), hasil belajar kognitif rata-rata 88,30, daya serap klasikal 88,30, ketuntasan klasikal mencapai 87,5\%, afektif, siklus II rata-rata 3,55 (membudaya) dan psikomotor siklus I rata-rata rata-rata 3,8 (membudaya).

\section{Pembahasan}

Hasil penelitian selain menggambarkan peningkatan aktivitas siswa dalam kelompok investigasi, juga memberikan gambaran hasil belajar siswa secara utuh yaitu hasil belajar kognitif, afektif dan psikomotor.

Merujuk pada hasil yang dipaparkan di atas, dapat dijelaskan bahwa pembelajaran yang melibatkan guru sebagai pemberi informasi dalam pembelajaran tidak memberikan pengalaman bermakna bagi siswa. Berhasil atau tidaknya suatu proses pembelajaran sangat ditentukan oleh optimalnya setiap aktivitas yang dilakukan baik oleh siswa maupun oleh guru. Hasil ini sejalan dengan apa yang dikemukakan oleh

Slavin (2005) bahwa kemampuan perencanaan kooperatif harus diperkenalkan secara bertahap ke dalam kelas dan dilatih dalam berbagai situasi sebelum kelas tersebut melaksanakan proyek investigasi berskala penuh. Selama pelaksanaan pembelajaran, guru melakukan tugasnya dengan sangat baik. Hal ini terlihat dari perolehan nilai secara kelompok pada aktivitas belajar kelompok. Guru dengan cermat memperhatikan setiap aktivitas yang dilakukan siswa baik secara individual maupun kelompok.

Sikap ketergantungan antar anggota kelompok tidak terlihat dari setiap aktivitas siswa. Siswa yang rendah kemampuan belajarnya berinteraksi lebih optimal dan saling memberi informasi antara satu dengan yang lainnya. Siswa menjadi lebih percaya diri dalam memberikan komentar dan pendapatnya pada kelompoknya. Siswa mengoptimalkan kerjasama dalam kelompok daripada mengandalkan kemampuan individual. Hasil penelitian 
ini sesuai pernyataan Slavin (2005) bahwa siswa dalam kelompok mengumpulkan, menganalisis,nmembuat kesimpulan secara bersama dan mengaplikasikan pengetahuan baru sebagai resolusi atas masalah yang diteliti oleh

kelompoknya.Kerjasama memberikan kontribusi terhadap pengalaman belajar, sehingga siswa memiliki pengetahuan yang memadai setelah diberikan tes. Selama kegiatan pembelajaran berlangsung, guru menjadi fasilitator, motivator dan evaluator yang bijak.

Guru tidak sepenuhnya melibatkan diri sebagai pemberi informasi, tetapi guru cenderung terlibat sebagai pembimbing dan memberikan arahan dan siswa menjadi pelaku yang aktif. Arahan dan penguatan-penguatan tentang pentingnya kerjasama dalam satu tim lebih dipahami oleh siswa sehingga siswa melakukan setiap aktivitas dengan optimal. Hal ini sejalan dengan pernyataan Slavin (2005) bahwa guru yang melaksanakan proyek group investigation cukup berperan sebagai nara sumber dan fasilitator. Guru dapat membantu siswa yang memiliki kesulitan dalam interaksi kelompok, berperan sebagai penasihat, dan berkolaborasi dalam mengevaluasi pembelajaran siswa. Oleh karena itu, berdasarkan hasil pada siklus II, dapat disimpulkan bahwa aktivitas siswa baik secara individu mapun secara kelompok (aktivitas sosial, afektif, serta kemapuan psikomotor siswa) terlaksana dengan optimal sehingga pencapaian hasil belajar/ketuntasan belajar setelah dilakukan tes akhir mencapai kriteria ketuntasan yang ditetapkan. Melihat proses yang terjadi dalam pembelajaran menggunakan model pembelajaran tipe group investigation, kemampuan berpikir siswa menjadi lebih baik dan memberikan kontribusi yang baik terhadap kemampuan belajarnya. Kontruktivitas model pembelajaran kooperatif tipe group investigation menjadikan siswa sebagai individu yang bijak dalam menjalani kehidupan bermasyarakat.

Siswa dapat belajar bekerjasama dengan solidaritas yang tinggi dalam melakukan berbagai kegiatan, mampu menyusun suatu perencanaan atau planning terhadap aktivitas yang akan dilakukan, siswa dapat menginvestigasi atau melakukan tukar informasi, berdiskusi, mengkarifikasi, mengumpulkan informasi, menganalisis data, dan membuat laporan secara ilmiah. Hasil pencapaian ini berkaitan dengan hasil penelitian yang dilakukan oleh Nasrudin dan Utiya (2010), bahwa penerapan model Group Investigation dapat meningkatkan keaktifan siswa dalam belajar sains Pembelajaran group investigation memberikan kesempatan kepada siswa untuk dapat mengorganisasikan setiap kemampuan atau kompetensi yang ada dalam dirinya, sehingga siswa dapat melakukan setiap kegiatannya secara kontruktif melalui pengamatan ilmiah, evaluasi, mengajukan pertanyaan atau menanggapi presentasi kelompok penyaji, dan memberikan saran atau ktitikan positif.

Selain itu, siswa antusias mencatat hasil presentasi dan menghargai kelompok lain yang lebih baik dari kelompoknya pada forum diskusi yang dilakukan. Hasil penelitian ini, merupakan suatu penilaian proses dan pengenalan yang akan tersimpan dalam jangka waktu lama atau pengalaman belajar yang tidak mudah dilupakan oleh siswa, karena hasil belajar turut serta dalam membentuk pribadi individu yang selalu ingin mencapai hasil yang lebih baik lagi sehingga akan merubah cara berpikir serta menghasilkan perilaku kerja yang lebih baik. Tiga ranah pencapaian hasil belajar yang merupakan hasil dari proses pembelajaran pada penelitian ini yaitu ranah kognitif ranah afektif dan psikomotor. Ranah kognitif lebih diarahkan pada pemahaman konsep melalui tes hasil belajar yang diberikan pada setiap akhir pembelajaran. Sementara, hasil belajar afektif adalah hasil penilaian perilaku dan kemampuan melakukan tindakan-tindakan positif baik secara individual maupun secara kelompok. Hasil ini berkaitan dengan hasil penelitian Fitriana (2011) bahwa siswa-siswa yang diberi pembelajaran dengan model pembelajaran cooperative type group investigation prestasi belajarnya menjadi lebih baik.

Hasil penilaian aktivitas kelompok dan psikomotor yang diperoleh pada penelitian ini menunjukkan pentingnya suatu kerjasama dalam sebuah kelompok investigasi. Hal ini sejalan dengan pernyataan Slavin dalam Rohmawati dan Syarief (2013) bahwa pembelajaran group investigation merupakan suatu model pembelajaran yang membentuk siswa agar dapat memecahkan masalahnya secara bersama-sama sebagai tugas kelompok dengan tanggung jawab secara individu, sehingga dapat memancing siswa kritis dan kreatif dalam menggali pemahaman.

Investigasi kelompok memanfaatkan ketertarikan individu dan memberikan kesempatan untuk mengontrol pembelajaran mereka. Pendapat tersebut mengasumsikan Jurnal IImiah Pendidikan Profesi Guru| 248 
bahwa dalam pembelajaran dengan menggunakan model group investigation disesuaikan dengan minat ketertarikan siswa tentang apa yang hendak mereka pelajari, dari hal tersebut siswa diberi kebebasan untuk menentukan apa yang mereka pelajari di dalam kelas.

Berdasarkan hasil yang diperoleh selama pelaksanaan tindakan, aktivitas guru dan siswa dilaksanakan secara optimal. Hal ini terlihat dari aktivitas guru dan siswa yang dilakukan dengan kategori baik/sangat baik,

ketuntasan yang mencapai criteria keberhasilan yang ditetapkan, peningkatan sikap soaial, afektif, psikomotor serta optimalnya aktivitas kelompok yang terlihat dari persentase keberhasilan dalam kelompok dengan kategori sangat baik. Dari hasil analisa data yang disajikan, baik hasil belajar aspek kognitif, aspek afektif, dan aspek psikomotor, menunjukkan model pembelajaran kooperatif group investigation dapat meningkatkan aktivitas dan hasil belajar IPA pada siswa kelas V SD Negeri 3 BanjarJawa

\section{SIMPULAN DAN SARAN}

Berdasarkan hasil penelitian dan pembahasan, penggunaan model pembelajaran group investigation dapat meningkatkan Aktivitas guru dan siswa kelas V SD Negeri 3 Banjar Jawa, dan menujukkan hasil belajar kognitif, afektif dan psikomotor. Tercapainya kriteria ketuntasan secara klasikal, dipengaruhi oleh optimalnya aktivitas guru dan siswa selama proses pembelajaran menggunakan model group investigation.

Berdasarkan hasil penelitian dan pembahasan yang telah diuraikan, dapat disimpulkan bahwa penerapan model pembelajaran kooperatif tipe Group Investigation berbantuan media visual dapat meningkatkan hasil belajar IPA siswa kelas VB semester I tahun pelajaran 2018/2019 di SD Negeri 3 Banjar Jawa.

Hasil analisis siklus I yaitu persentase hasil belajar matematika mencapai $74,06 \%$ berada pada kategori sedang, namun masih ada satu siswa yang berada pada kategori kurang tinggi dan beberapa siswa berada pada kategori cukup tinggi. Sedangkan pada siklus II hasil belajar IPA siswa mencapai $85,31 \%$ berada pada kategori tinggi.

Hal ini menunjukkan terjadi peningkatan pada hasil belajar IPA siswa sebesar $11,25 \%$ dari siklus I ke siklus II dan terjadi peningkatan hasil belajar IPA secara individu maupun secara rata-rata klasikal secara keseluruhan.

Berdasarkan hasil penelitian, peneliti merekomendasikan saran yaitu:

1. Disarankan kepada seluruh siswa khususnya di SD Negeri 3 Banjar Jawa untuk memanfaatkan pengalaman belajar yang didapat

setelah diterapkan model pembelajaran kooperatif tipe Group Investigation berbantuan media visual, sehingga hasil belajar IPA dapat terus meningkat.

2. Sesuai dengan hasil penelitian tindakan kelas ini, diharapkan kepada guru (pengajar) agar

dapat mempertimbangkan penerapan model pembelajaran kooperatif tipe Group Investigation berbantuan media visual ini sebagai salah satu alternatif

pilihan model pembelajaran dalam

pembelajaran IPA guna meningkatkan hasil belajar IPA yang dicapai siswa.

3. Sekolah yang menemukan permasalahan yang sama dengan penelitian ini agar menggunakan model pembelajaran kooperatif tipe Group Investigation berbantuan media visual dalam pembelajaran. Karena berguna bagi siswa untuk menemukan konsep-konsep IPA sehingga pelaksanaan kegiatan pembelajaran menjadi lebih efektif

4. Disarankan kepada peneliti lain yang berminat mengadakan penelitian lebih lanjut dan sejenis tentang penerapan model pembelajaran kooperatif tipe Group Investigation berbantuan media visual, hendaknya lebih memperhatikan kendala-kendala yang dihadapi siswa

dalam pembelajaran serta mengupayakan solusi pemecahan yang tepat agar penelitian yang dilaksanakan dapat mencapai hasil belajar IPA yang lebih maksimal. Penelitian ini dapat dijadikan acuan ataupun referensi demi ketuntasan penelitian selanjutnya.

5. Model pembelajaran kooperatif tipe group investigation dapat digunakan sebagai inovasi dalam meningkatkan kualitas pembelajaran sains dan digunakan atau diterapkan pada pokok bahasan IPA lainnya, atau pada mata pelajaran lain.

6. Hasil penelitian dapat dijadikan rujukan untuk melakukan penelitian pada pokok bahasan lain, subjek lain, maupun mata pelajaran lain.

7. Guru, harus memperhatikan dengan cermat setiap sintaks atau langkah-langkah Model pembelajaran kooperatif tipe group investigation dan memiliki wawasan yang memadai tentang

karakteristik model pembelajaran kooperatif tipe group investigation, sebelum menerapkan dalam proses pembelajaran. 


\section{DAFTAR RUJUKAN}

Agung, Gede. 2012. MetodelogiPenelitian Pendidikan. Singaraja:Universitas Pendidikan Ganesha.
------. 2005. Metodelogi PenelitianPendidikan.Singaraja: UniversitasPendidikan Ganesha.
------,2010. Pengantar EvaluasiPendidikan. Singaraja: Universitas Pendidikan Ganesha.

------. 2014. Metodologi Penelitian Pendidikan. Singaraja: Aditya Media Publishing.

Aqib, Zainal. 2013. Model - Model, Media dan Strategi Pembelajaran Kontekstual.Bandung:Yrama Widya.

Laporan Hasil Observasi”. Skripsi (tidak diterbitkan). UPI..

Huda,Miftahul. 2013. Model - Model

Pengajaran dan Pembelajaran. Malang:Pustaka Pelajar.

Iswardati. 2016. "The Implementation of Group Investigation to Improve the Students' Speaking Skill". Desertasi (tidak diterbitkan). Dinamika IImu.

Jihad, Asep dan Abdul Haris. Evaluasi Pembelajaran. Yogyakarta: Multi Presindo.

Kurniawan. Deni. 2014. Pembelajaran TEMATIK (Teori, Praktik, dan Penilaian). Bandung: Alfabeta.

Muliyantini, Ni Luh Putu. 2017. "Penerapan Model Pembelajaran Group Investigation (Gi) Untuk Meningkatkan Hasil Belajar Ipa Kelas V". Skripsi (tidak diterbitkan). Fakultas Ulmu Pendidikan. Undiksha.

Sadiman, Arief dkk.2011. Media Pendidikan. Jakarta:Rajawali Pers

Sugiyono. 2013. Metodelogin Penelitian Pendidikan.Bandung: Alfabeta.

Sukardi, H.M. 2008. Evaluasi Pendidikan Prinsip dan Operasionalnya. Yogyakarta: Bumi Aksara.

Susanto. Ahmad. 2014. Teori Belajar dan Pembelajaran di Sekolah Dasar. Jakata : Kencana.

Shoimin, Aris. 2014. 68 Model Pembelajaran Inovatif dalam Kurikulum 2013. Yogyakarta:AR-Ruzz Media

Wiyani, Novan Ardy. 2013. Desain Pembelajaran Pendidikan. Jakarta: ARRUZZ.

Widoyoko, Eko Putro. 2014. Penilaian Hasil Pembelajaran di Sekolah. Yogyakarta: Pustaka Pelajar. 